\title{
Relationship between Corporate Social Performance, Corporate Financial Performance and Financial Risk in Indian Firms
}

\author{
D. Dhanasekar, M. Selvam, P. Amrutha
}

\begin{abstract}
This study examines the relationship between Corporate Social Performance and Corporate Financial Performance and Financial Risk of BSE top 10 companies in India. The variables of Corporate Social Performance and Financial Performance and Financial Risk were used in this study. There was positive relationship between Corporate Social Performance, Corporate Financial Performance and Financial Risk, at Bajaj Finance Ltd, Reliance Industries Ltd, Bajaj Auto Ltd, State Bank of India, Hindustan Unilever Ltd, Asian Paints Ltd and Bharathi Airtel Ltd. The novelty of the study is that the analysis of this study focuses on CSP, CFP and Financial Risk in respect of Indian firms.
\end{abstract}

Keywords: Corporate Social Performance, Corporate Financial Performance, Corporate Social Responsibility and Financial Risk.

\section{INTRODUCTION}

\section{Corporate Social Performance}

Corporate Social Performance (CSP) is defined as a business organization's configuration of principles of social responsibility, processes of social responsiveness, and observable outcomes as they relate to the societal relationships of firms [1]. CSP is a complex web of interconnected cause and effect. It conceives of business as a social institution, with both power and responsibility. CSP covers the full range of antecedent and outcomes of business organization operations and does not focus only on maximizing shareholders' wealth. To ensure the strategic social responsibility, the management of the companies need to have systems, for objectively measuring their commitment to CSR practices, commonly known as Corporate Social Performance (CSP). Carroll (1979) introduced conceptual models of CSP and opted for 'performance', as the operative term because the 'responsibility' of firms is not measurable. In line with Carroll, CSP is defined as an objective and operational measures of CSR. CSP is also described as a multidimensional construct, comprising initiatives undertaken by a company under four broad domains - the natural environment, the treatment of employees, workplace

Revised Manuscript Received on December 22, 2018

* Correspondence Author

D. Dhanasekar, Ph. D., Research Scholar in Management, Department of Commerce and Financial Studies, Bharathidasan University, Tamil Nadu, India. Email: dhanasekar48@bdu.ac.in

Dr. M. Selvam, Dean,Faculty of Management, Professor and Head, Department of Commerce and Financial Studies, Bharathidasan University, Tamil Nadu, India.Email: drmselvam@yahoo.co.in

P. Amrutha Ph. D., Research Scholar in Management, Department of Commerce and Financial Studies, Bharathidasan University, Tamil Nadu, India.. Email: amrutha.pavith@gmail.com diversity, and customer, product and other issues (Meijer and Schuyt, 2005).

\section{Research Definition of Corporate Social Performance}

Early definitions of corporate social responsibility did not help theoretical development nor could they be operationalized for research purposes.

- According to Davis (1973), CSR is the consideration of firms and response to the issues, beyond the narrow economic, technical and legal requirements, to accomplish social benefits of the firms, along with the traditional economic gains, which the firm seeks.

- The fundamental idea of CSR is that business corporations have an obligation to work for social betterment (Frederick, 1994).

- Wood (1991) clearly defined CSP as the principles, process, and outcomes of businesses. It is the change to better assess the stakeholders implications of CSP measures. Wood (2010) also argued for 'CSP as an overarching, multi-dimensional construct, where vast literature on organizational culture, managerial decision making or employee relations practices 'waits to be brought into the field of CSP.

\section{Corporate Financial Performance (CFP)}

Corporate Financial Performance (CFP) is a subjective measure of how well a firm can use assets from its primary mode of business and generate revenues. The term CFP is also used as a general measure, to find out the overall financial health of a firm, over a given period of time and could be used to compare similar firms across the same industry or to compare industries or sectors in aggregation. The financial performance (profitability) of firms was measured generally by using three accounting variables: Return on Assets (ROA), Return on Equity (ROE) and Return on Sales (ROS), providing a range of measures, used to assess CFP by investors (Sandra et al., (1997). CFP means different things to different stakeholders. The measures of $\mathrm{CFP}$ in academic research have largely converged into the trichotomy of CFP, proposed by Orlitzky et al., 2003, namely: 1) Market-Based, 2) Accounting-Based and 3) Perceptual CFP Measures. Market-based measures of CFP include variables such as price per share or share price appreciation. They reflect the notion that the shareholders are a primary stakeholder group (Cochran and Wood, 1984). The accounting based measures, such as the Return on Assets (ROA), Return on Equity (ROE), or Earnings Per Share (EPS) capture internal 
efficiency of firms. The measures of CFP provide subjective estimates of financial performance of firms, for instance, soundness of financial position and better use of corporate assets or financial goal achievements relative to competitors (Conine and Madden, 1987; Reimann, 1975; Wartick, 1988). It is a known fact that both CSP and CFP are difficult to measure. Under such circumstances, Lu et al., 2014 vividly suggested a general principle of using more objective CFP measures. The selection of CFP measures is also subject to data accessibility and their suitability to the characteristics of the industry within which the companies are functioning. Moreover, it is advisable to combine the different types of measures, either market or accounting-based, when they could help better to probe the financial performance of firms.

\section{Financial Risk}

Financial Risk is defined as the maximum amount of uncertainty, that someone is willing to accept, while making a financial decision and the financial risk reaches into almost every part of economic and social life (John E. Grable, 2000). The importance of developing better financial decisions, in securing long-term economic well-being, is rarely disputed, as establishing healthy saving and investing habits can move closer to achieve the financial security and stability (Winterich \& Nenkov, 2015). Implied in this process of financial risk is the amount of financial risk one is willingness to accept, depending upon the ability of the individual to appropriately invest in the future (Nuttall \& Jahnke, 2000). There is a need to better understand the link between personal traits of individual and the risk-related decisions, that ultimately impact financial well-being (Brüggen, Hogreve, Holmlund, Kabadayi, \& Löfgren, 2017). The role of implicit self-theories is the acceptance of financial risk in investment. Although the importance of assessing financial risk tolerance is well documented, in practice, the assessment process tends to be very difficult, due to the subjective nature of risk taking.

\section{LITERATURE REVIEW}

The earlier research studies, relating to Corporate Social Performance, Corporate Financial Performance and Financial Risk, are reviewed below.

Hill et al., (2006) reported that there was positive, negative, or neutral impact of CSP on performance of firms. The study clearly supported a positive relationship between CSP and CFP. The neutral relationship is supported by the argument that the environment in which firms and society operate is complex. The simple and direct relationship between CSP and FP did not exist (Waddock \& Graves, 1997). Kim and Statman, (2012) found that corporate financial performance increases with CSP up to a certain point but diminishes beyond that point. Recent surveys by Callan and Thomas, 2009; Margolis and Walsh, 2003 highlighted the difficulty of comparing such prior studies because of their lack of uniformity in measurement for both financial performance and CSP. But, in a general sense, there was a positive relationship between corporate social and financial performance.

Froot et al., (1993) offered reasons for managers not concerning themselves with the active management of risks in their organizations. It is found that management need to maximize the expected profits, taking into account its variability/volatility (financial risk). Glaum (2000) examined the financial risk management, that has received increased attention, over the past years. Eichhorn (2004) found that the financial risks were in different forms. There were external financial risks, depending upon changes in financial markets. On the other hand, there were internal financial risks, where the company itself was the source of the risks.

The above studies provided an overview, about the relationship between CSP, CFP and Financial Risk of sample companies. But this study would provide an empirical evidences, showing the relationship between CSP, CFP and Financial Risk, in BSE top 10 companies, in India.

\section{STATEMENT OF THE PROBLEM}

The Corporate Social Performance is an appropriate subject of research study as it is an emerging issue in India. The previous research studies were undertaken with limited data, examining the relationship between CSP and CFP and produced conflicting results. Some studies found that there was positive association between CSP and CFP, but there are many problems in using appropriate variables for exactly measuring CSP and CFP. The measurement of CSP accurately is an important research issue, from the point view of different types of stakeholders. Therefore, this study attempts to overcome the problems of measurement of CSP and CFP \& Financial Risk. In this research study, an attempt has been made, to examine the relationship between Corporate Social Performance and Corporate Financial Performance and Financial Risk, in BSE Top 10 companies, in India.

\section{NEED OF THE STUDY}

Firms are expected to maintain optimal relationship between CSP and CFP and Financial Risk, in order to fulfill the demands of various stakeholders. In India, there is no database on CSP and CFP. This research study would develop the data, relating to Corporate Social Performance and Corporate Financial Performance, about Indian firms. This study would also help all the stakeholders of corporate firms, to understand the relationship between Corporate Social Performance and Corporate Financial Performance and Financial Risk of firms in India.

\section{OBJECTIVE OF THE STUDY}

The main aim of the study was, to analyze normality and relationship between Corporate Social performance and Corporate Financial Performance and Financial Risk, in BSE Top 10 Companies of India.

\section{HYPOTHESES OF THE STUDY}

NH1: There is no normality of Corporate Social Performance and Financial Performance \& Financial Risk of BSE top companies in India.

NH2: There is no relationship between Corporate Social Performance and Financial Performance of BSE top companies in India.

NH3: There is no relationship between Corporate Social Performance and Financial Risk of BSE top companies in India. 


\section{RESEARCH METHODOLOGY}

\section{a. Selection of Sample Size}

The Data Portal of National Corporate Social Responsibility publishes the top ten CSR-spending companies in India. For the purpose of this study, those top companies, that found place in BSE thirty firms during the study period, were selected for this study. There were $10 \mathrm{BSE}$ companies, which found a place in Data Portal. Hence the study covered the sample size of BSE top 10 companies such as 1. Bajaj Finance Ltd, 2. Reliance Industries Ltd, 3. Bajaj Auto Ltd, 4. Tata Motors Ltd, 5. State Bank of India, 6. Hindustan Unilever Ltd, 7. NTPC Ltd, 8. ITC Ltd, 9. Asian Paints Ltd and 10. Bharathi Airtel Ltd.

\section{b. Sources and Collection of Data}

The study mainly depended on secondary data. The Corporate Social Performance was measured, using a variable, CSR Spent Amount, while the Corporate Financial Performance variables included Sales, Total Asset, Research and Development and Advertising Expenses. The Financial Risk variable includes Market Value. The required data were collected from websites of www.csrbox.com \& www.csr.gov.in and www.ntdv profit.com, PROWESS database and websites of respective companies. The other required data were collected from various books, journals and magazines.

\section{c. Period of the Study}

The present study covered a period of five years from 2014 to 2018 .

\section{d. Tools used for the Analysis}

$>$ Descriptive Statistics (To analyze the normality of CSP, CFP \& Financial Risk for sample companies in India)

$>$ Correlation Analysis (To analyze the relationship CSP, CFP \& Financial Risk for sample companies in India)

VIII. Correlation between Corporate Social Performance, Corporate Financial Performance and Financial Risk for Sample Companies in India

a) Descriptive Statistics of Corporate Social Performance, Corporate Financial Performance \& Financial Risk for sample Companies.

b) Correlation between Corporate Social Performance and Financial Performance of sample Companies, and

c) Correlation between Corporate Social Performance and Financial Risk of sample Companies.

a) Descriptive Statistics of Corporate Social Performance, Corporate Financial Performance \& Financial Risk for Sample Companies

The results of descriptive statistics, for sample companies, in respect of CSP, CFP and Financial Risk, during the study period from 2014 to 2018, are displayed in Table-1. The three main variables, namely, Corporate Social Performance (CSR spent amount) and Corporate Financial Performance variables (Sales, Total Asset, Research and Development and Advertising Expenses) and Financial Risk variable (Market Value), were used in this study, to examine normality of data. According to Table-1, the mean values of all the sample variables and sample companies were positive, during the study period.
The detailed analysis of the Table reveals that the Reliance Industries Ltd registered a mean value for CSP, at 2.80057 while the Tata Motors Ltd received the lowest mean value, for CSP, at 1.334802. The leading public sector bank, namely, State Bank of India recorded the highest value, for CFP, at 6.38162 for Total Assets while the famous Indian multinational conglomerate company, namely, Reliance Industries Ltd registered the lowest mean value of CFP variable (sales), at 0.19449 , during the study period. The leading global telecommunication company, namely, Bharathi Airtel Ltd, recorded the highest mean value of Financial Risk (Market Value), at 4.79803 and Reliance Industries Ltd, being ranked 106 by the Fortune 500 (https://www.fortuneindia.com/investing/reliance-indust ries-is-top-ranked-Indian-company-on-fortune-global -500/103447), recorded the lowest mean value on Financial Risk (Market Value of 1.79545), during the study period. It is to be noted from the mean values that all the variables attained positive mean values against all sample firms. This indicated the fact that the data of sample variables, regarding CSP and CFP \& Financial Risk in BSE listed companies in India, attained normal distribution of data.

It is interesting to note that among India's largest players, in the burgeoning consumer finance segment, Bajaj Finance Ltd recorded the highest Standard Deviation value, at 0.1624, for CSP while the Bajaj Auto Ltd registered the lowest value (0.03182), for CSP. The highest income tax payer(www.moneycontrol.com/ stocks/ marketinfo / tax / nse / index.html), Reliance Industries Ltd, received the highest standard deviation of CFP (sales at 0.18759) while the India's foremost private sector company, namely, ITC Ltd recorded the lowest value of CFP (Advertising Expenses at 0.0296$)$. The world's largest manufacturers of motor cycles company, namely, Bajaj Auto Ltd registered the highest standard deviation value of financial risk (Market value at 1.04108) and the India's largest power utility company, namely, NTPC Ltd, had reported the lowest standard deviation value of financial risk (Market Value), at 0.0706 , during the study period. It is to be noted that all the standard deviation values, for all variables, were positive, which indicated that there was normal distribution of data sample variables during the study period.

The State Bank of India earned the skewness value of 1.082485 , for CSP (positive) while the Bajaj Finance Ltd received the lowest value of 0.138162 , for CSP (positive), during the study period. But the State Bank of India registered the highest skewed value of CFP variable, namely, $\mathrm{R} \& \mathrm{D}$ at 0.96193 (positive) while the ITC Ltd recorded the least value but positive (0.004593) for CFP variable (for Total Assets). Regarding Bajaj Auto Ltd, the highest but positive skewed value for Financial Risk variable, namely, Market Value, was recorded at 1.236443 and the Bajaj Finance Ltd registered the lowest value but positive, for market value, at 0.074904 , during the study period. The analysis of skewness for all the sample companies and all variables, showed that the data were normally distributed during the study period.

According to Kurtosis, value greater than three, indicates high normality, which is called Leptokurtosis while value less than three, indicates low or no normality, which is called platykurtosis. The Bharathi Airtel Ltd recorded the kurtosis value of 2.802095 (positive), for CSP. The State Bank of

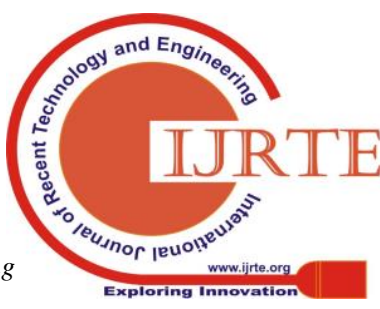


India registered kurtosis value for CFP variable, namely, $\mathrm{R} \& \mathrm{D}$, at 2.66544 (positive) during the study period. Kurtosis value of Bajaj Auto Ltd was positive at 2.896235. The overall analysis of Table- 1 indicated that the data of all sample variables were normally distributed during the study period. Therefore, the null hypothesis - (NH1), There is no normality in the CSP and CFP \& Financial of BSE companies in India, was rejected.

\section{b) Relationship between Corporate Social Performance and Financial Performance of sample Companies.}

One of the objectives of this study was to find out the relationship between CSP and CFP, in respect of BSE listed sample firms. The results of correlation analysis, for BSE listed sample companies during the study period from 2014 to 2018, are displayed in Table-2. According to the analysis of correlation, there was positive correlation between Corporate Social Performance (CSR spent Amount) and Financial Performance (Sales at 0.979 and Total Asset at 0.998, Research and Development at 0.984, Advertising Expenses at 0.829), in the case of Bajaj Financial Ltd. Regarding Reliance Industries Ltd, the analysis of relationship between CSP and CFP (Sales at 0.963, Total Assets at 0.991, R \& D at 0.982 and Advertising expenses at 0.263 ) was positive during the study period. Another sample firm namely Bajaj Auto Ltd shows that the relationship between CSP and all the variables of CFP was positive (Sales, Total Assets, R \& D and Advertising Expenses, with values of 0.887, 0.914, 0.83 and $0.829)$ respectively. It is interesting to note that for India's largest auto mobile sector company, namely, Tata Motors $\mathrm{Ltd}$, the correlation between CSP and CFP variable, namely, Total Assets was positive at 0.462 while the Sales, R \& D and Advertising expenses were negatively correlated, during the study period. As far as State Bank of India was concerned, the relationship between CSP and CFP variables (namely Sales, Total Assets, and Advertising expenses) were positive with the values of $0.086,0.02$ and 0.711 respectively. Regarding India's largest fast moving consumer goods company, namely, Hindustan Unilever Ltd, the analysis of correlation between CSP and CFP variables were positive, with values of 0.842 for sales and 0.982 for Total Assets while there were negative values of -0.71 for $R \& D$ and -0.907 for Advertising Expenses respectively. For the NTPC Ltd, the relationship between CSP and CFP variable, namely, Advertising Expenses was positive at 0.751 and variables for CFP (sales, Total Assets and R\&D) were negatively correlated during the study period. Regarding ITC Ltd, CSP and CFP variables like Total Assets and Advertising Expenses were positive with values of 0.992 and 0.331 and there were negative values of CFP variables, namely, Salas and R\&D (-0.141 and -0.625) respectively. As far as Asian Paints Ltd was concerned, there was positive relationship between CSP and CFP (Sales at 0.938, Total Assets at 0.995, $\mathrm{R} \& \mathrm{D}$ at 0.954 and Advertising expenses at 0.19). For Bharathi Airtel Ltd, correlation between CSP and CFP variables (Sales, Total Assets, R \& D and Advertising expenses with the value of $0.898,0.963,0.145$ and 0.97 ) was positive during the study period. The overall analysis indicated that the correlation between CSP and CFP was positive. Therefore, the Null Hypothesis - (NH2), There is no relationship between CSP and CFP in BSE listed companies in India, was rejected.

c) Correlation between Corporate Social Performance and Financial Risk of sample Companies
The results of correlation analysis for sample companies, in respect CSP and Financial Risk during study period from 2014 to 2018, are displayed in Table-2. In respect of Indian non-banking financial company, namely, Bajaj Finance Ltd, the correlation analysis indicated that the CSP and Financial Risk variable (Market Value) was negative at -0.176 . Regarding the largest public trading company, namely, Reliance Industries Ltd, the analysis of relationship between CSP and Financial Risk (Market Value) revealed positive value, at 0.92 , during the study period. The correlation analysis for Bajaj Auto Ltd, showed that the sample variables of CSP and Financial Risk (market value) were correlated, at 0.485 (positive value). As far as Tata Motors Ltd was concerned, the correlation analysis of CSP and Financial Risk indicate negative value of -0.152 . In respect of State Bank of India, the correlation between CSP and market value of Financial Risk shows that there was negative value (-0.356). Regarding Hindustan Unilever Ltd, the correlation between CSP and Financial Risk was negative, with the value of -0.68 , during the study period. The correlation analysis for NTPC Ltd clearly revealed that the relationship between CSP and Financial Risk variable was negative (Market Value was at -.296). In respect of ITC Ltd, the correlation between CSP and Financial Risk had recorded a positive value at 0.998. As far as Asian Paints Ltd was concerned, the correlation value between CSP and Financial Risk was positive, with value of 0.682, during the study period. The Bharathi Airtel Ltd witnessed positive relationship between CSP and Financial Risk, at 0.915 , during the study period. The overall analysis of correlation between CSP and Financial Risk, for the sample companies (Reliance Industries Ltd, Bajaj Auto Ltd, ITC Ltd, Asian Paints Ltd and Bharathi Airtel Ltd have got positive values and the Bajaj Finance Ltd, Tata Motors Ltd, State Bank of India, Hindustan Unilever Ltd and NTPC Ltd) reported negative values, during the study period. Therefore, the null hypothesis - (NH3), There is no relationship between Corporate Social Performance and Financial Risk of BSE top Companies in India, was partially rejected.

\section{CONCLUSIONS}

The analysis of relationship, between Corporate Social Performance, Corporate financial performance and Financial Risk, in BSE listed companies in India, is a timely research. It contributes to the inconclusive, yet popular, discussion of relationship between CSP and CFP and Financial Risk. The stakeholder responses, to each of these elements, are likely to moderate the relationship between CSP and its CFP outcomes. The demonstrate not only that CSP reputation, as a function of stakeholder responses to CSP trajectory, matters, but that there are features of a firm's CSP history that significantly impact the payoffs, that can be expected from increasing CSP. Waddock and Graves, (1997) argued that the problem of measuring CSP was the primary reason, for the confliticting results, regarding the relationship between CSP and CFP. The positive relationship between CSP and CFP was found by Bowman, (1980) and Fry and Hock, (1976). Some other studies by Freedman and Jaggi, (1982) and Gerwin Vander Lean et al., (2008), found negatives relationship between CSP and CFP \& Financial Risk, which was confirmed by the present study too.

The results of this study revealed that the there was

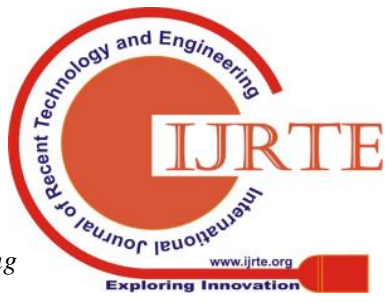


positive relationship between Corporate Social Performance and Corporate Financial Performance as well as between Corporate Social Performance and Financial Risk in India. The sample variables of Corporate Social Performance and variables of Corporate Financial Performance like Sales, Total Assets, Research and Development and Advertising Expenses, reported normal distribution and the Financial Risk variable, namely market value, was normally distributed during the study period. More research work is needed, to determine the extent to which these results could be generalized.

The results of the current study have contributed to both methodological and theoretical fronts. This study discussed the role of the characteristics of the sample variables, in shaping the relationship between Corporate Social Performance and Corporate Financial Performance and financial Risk.

\section{LIMITATIONS OF THE STUDY}

$>$ The study covered only top ten CSR Firms.

> The study period was only from 2014 to 2018 .

$>$ The study mainly focused on normality and relationship between CSP and CFP and Financial Risk.

\section{SCOPE FOR FURTHER RESEARCH}

The future research on this topic is needed to measure Corporate Social Performance and Corporate Financial Performance. The future research could apply the sample, taken from a longer period of time, which would predictive value of the improve the research. Also different types of variables could be applied, in order to find the impact and relationship between CSP and CFP in Indian firms.

Table - 1: Descriptive Statistics of Corporate Social Performance and Financial Performance \& Financial Risk for BSE top 10 Companies during the Study Period from 2014 to 2018

\begin{tabular}{|c|c|c|c|c|c|c|}
\hline \multirow{2}{*}{ Variables } & \multirow{2}{*}{ CSP } & \multicolumn{4}{|c|}{ Corporate Financial Performance } & \multirow{2}{*}{$\begin{array}{c}\text { Financial Risk } \\
\text { MV }\end{array}$} \\
\hline & & SALES & TA & R\&D & $\mathbf{A E}$ & \\
\hline \multicolumn{7}{|c|}{ Bajaj Finance Ltd } \\
\hline Mean & 1.3988 & 0.95853 & 4.61575 & 1.97926 & 1.64568 & 3.94404 \\
\hline Median & 1.39072 & 0.96982 & 4.61367 & 1.98166 & 1.61548 & 3.93274 \\
\hline Maximum & 1.5955 & 1.055 & 4.82542 & 2.04258 & 1.83206 & 4.33481 \\
\hline Minimum & 1.21827 & 0.83948 & 4.41023 & 1.91116 & 1.5197 & 3.57588 \\
\hline Std. Dev. & 0.16241 & 0.09211 & 0.18112 & 0.05458 & 0.13311 & 0.34102 \\
\hline Skewness & 0.138162 & -0.35888 & 0.0299 & -0.14226 & 0.710622 & 0.074904 \\
\hline Kurtosis & 1.655605 & 1.792546 & 1.56599 & 1.885115 & 2.073283 & 1.431407 \\
\hline \multicolumn{7}{|c|}{ Reliance Industries Ltd } \\
\hline Mean & 2.80057 & 0.19449 & 5.67524 & 3.582 & 3.64921 & 1.79546 \\
\hline Median & 2.79268 & 0.27416 & 5.68275 & 3.57978 & 3.57588 & 2.09767 \\
\hline Maximum & 2.89 & 0.36549 & 5.79066 & 3.69729 & 4.33481 & 2.14302 \\
\hline Minimum & 2.7267 & -0.041 & 5.56536 & 3.49739 & 2.96142 & 1.23045 \\
\hline Std. Dev. & 0.06819 & 0.18759 & 0.09365 & 0.07828 & 0.57082 & 0.45084 \\
\hline Skewness & 0.223336 & -0.36756 & 0.008097 & 0.445987 & 0.054841 & -0.44622 \\
\hline Kurtosis & 1.545929 & 1.316537 & 1.508363 & 1.990202 & 1.500325 & 1.25951 \\
\hline \multicolumn{7}{|c|}{ Bajaj Auto Ltd } \\
\hline Mean & 1.96989 & 0.48996 & 4.25465 & 3.47321 & 3.47321 & 3.81784 \\
\hline Median & 1.97731 & 0.4843 & 4.21713 & 3.52164 & 2.59695 & 3.5557 \\
\hline Maximum & 1.99991 & 0.57054 & 4.37693 & 3.52403 & 2.64087 & 5.6109 \\
\hline Minimum & 1.93616 & 0.42814 & 4.16872 & 3.34573 & 2.41885 & 3.08437 \\
\hline Std. Dev. & 0.03182 & 0.05179 & 0.08905 & 0.07787 & 0.09573 & 1.04108 \\
\hline Skewness & -0.18886 & 0.564202 & 0.457253 & -1.0114 & -0.6199 & 1.236443 \\
\hline Kurtosis & 1.234396 & 2.472024 & 1.55002 & 2.407189 & 1.816958 & 2.896235 \\
\hline \multicolumn{7}{|c|}{ Tata Motors Ltd } \\
\hline Mean & 1.334802 & 0.566547 & 4.73818 & 0.808333 & 2.854279 & 2.308007 \\
\hline Median & 1.331225 & 0.60206 & 4.753399 & 0.792392 & 2.857441 & 2.338815 \\
\hline Maximum & 1.41397 & 0.7348 & 4.772412 & 0.875061 & 2.92858 & 2.482645 \\
\hline Minimum & 1.26998 & 0.340444 & 4.696657 & 0.770852 & 2.786879 & 2.156943 \\
\hline Std. Dev. & 0.052593 & 0.14538 & 0.037794 & 0.045003 & 0.052909 & 0.145977 \\
\hline Skewness & 0.4131 & -0.6029 & -0.30266 & 0.619139 & 0.165298 & -0.04831 \\
\hline Kurtosis & 2.335076 & 2.396525 & 1.210557 & 1.842241 & 2.067893 & 1.38919 \\
\hline \multicolumn{7}{|c|}{ State Bank of India } \\
\hline Mean & 2.06254 & 0.43654 & 6.38162 & 3.15351 & 5.48304 & 4.28340 \\
\hline Median & 2.05 & 0.42325 & 6.37247 & 3.11086 & 4.65747 & 4.55647 \\
\hline Maximum & 2.11727 & 0.49693 & 6.53842 & 3.3656 & 7.54308 & 734208 \\
\hline
\end{tabular}


Relationship between Corporate Social Performance, Corporate Financial Performance and Financial Risk in Indian Firms

\begin{tabular}{|l|r|r|r|r|r|r|} 
Minimum & 2.03743 & 0.3784 & 6.25352 & 3.02551 & 3.62496 & 3.62496 \\
\hline Std. Dev. & 0.03273 & 0.04465 & 0.11021 & 0.12816 & 1.8747 & 0.6543 \\
\hline Skewness & 1.082485 & 0.104746 & 0.32068 & 0.96193 & 0.295127 & 0.295127 \\
\hline Kurtosis & 2.621154 & 1.976939 & 1.916207 & 2.66544 & 1.231087 & 1.231087 \\
\hline
\end{tabular}

\begin{tabular}{|c|c|c|c|c|c|c|}
\hline \multirow{2}{*}{ Variables } & \multirow{2}{*}{ CSP } & \multicolumn{4}{|c|}{ Corporate Financial Performance } & \multirow{2}{*}{$\begin{array}{c}\text { Financial Risk } \\
\text { MV }\end{array}$} \\
\hline & & SALES & TA & R\&D & $\mathbf{A E}$ & \\
\hline \multicolumn{7}{|c|}{ Hindustan Unilever Ltd } \\
\hline Mean & 1.99556 & 0.78418 & 4.1534 & 1.26659 & 4.03221 & 3.2427 \\
\hline Median & 2.00736 & 0.78176 & 4.13837 & 1.20952 & 3.61331 & 3.23838 \\
\hline Maximum & 2.0543 & 0.91698 & 4.22773 & 1.4216 & 4.79116 & 3.45561 \\
\hline Minimum & 1.90266 & 0.66087 & 4.10845 & 1.18469 & 3.54033 & 3.10209 \\
\hline Std. Dev. & 0.06366 & 0.09074 & 0.04614 & 0.10611 & 0.63521 & 0.13362 \\
\hline Skewness & -0.50848 & 0.174502 & 0.85994 & 0.637766 & 0.419 & 0.74825 \\
\hline Kurtosis & 1.831431 & 2.500137 & 2.419459 & 1.717668 & 1.20481 & 2.435105 \\
\hline \multicolumn{7}{|c|}{ NTPC Ltd } \\
\hline Mean & 2.38664 & 0.43586 & 5.34464 & 2.77464 & 0.72727 & 1.97056 \\
\hline Median & 2.35765 & 0.43933 & 5.33272 & 2.96308 & 0.72917 & 1.98713 \\
\hline Maximum & 2.45252 & 0.49416 & 5.4285 & 2.99352 & 0.98363 & 2.04953 \\
\hline Minimum & 2.3439 & 0.32634 & 5.27014 & 2.45179 & 0.46389 & 1.88536 \\
\hline Std. Dev. & 0.05218 & 0.06809 & 0.06196 & 0.28425 & 0.19457 & 0.0706 \\
\hline Skewness & 0.427901 & -0.83697 & 0.216887 & -0.40583 & -0.04926 & -0.17202 \\
\hline Kurtosis & 1.288045 & 2.397837 & 1.775581 & 1.175072 & 2.020087 & 1.40026 \\
\hline \multicolumn{7}{|c|}{ ITC Ltd } \\
\hline Mean & 2.42645 & 0.88393 & 4.69348 & 1.28083 & 2.91309 & 3.68485 \\
\hline Median & 2.43976 & 0.88196 & 4.69924 & 1.26007 & 2.90085 & 3.8024 \\
\hline Maximum & 2.5089 & 0.92583 & 4.79505 & 1.34439 & 2.94755 & 4.04519 \\
\hline Minimum & 2.32822 & 0.84136 & 4.59361 & 1.25042 & 2.87794 & 3.01918 \\
\hline Std. Dev. & 0.06917 & 0.03947 & 0.07793 & 0.04076 & 0.0296 & 0.43197 \\
\hline Skewness & -0.31741 & 0.031554 & 0.004593 & 0.814954 & 0.136064 & -0.71055 \\
\hline Kurtosis & 1.946129 & 1.277589 & 1.813588 & 2.074572 & 1.439165 & 2.074553 \\
\hline \multicolumn{7}{|c|}{ Asian Paints Ltd } \\
\hline Mean & 1.59001 & 0.83172 & 3.94184 & 2.85611 & 2.76148 & 2.81443 \\
\hline Median & 1.60076 & 0.84696 & 3.94076 & 2.87541 & 2.74682 & 2.85486 \\
\hline Maximum & 1.67899 & 0.90634 & 4.06401 & 2.88315 & 2.86926 & 2.99049 \\
\hline Minimum & 1.47524 & 0.70157 & 3.82736 & 2.80024 & 2.70246 & 2.56554 \\
\hline Std. Dev. & 0.08791 & 0.07931 & 0.0998 & 0.03595 & 0.06683 & 0.1693 \\
\hline Skewness & -0.24222 & -0.93657 & 0.058001 & -0.8083 & 0.873819 & -0.5148 \\
\hline Kurtosis & 1.493865 & 2.554991 & 1.464154 & 2.047542 & 2.39243 & 1.910763 \\
\hline \multicolumn{7}{|c|}{ Bharathi Airtel Ltd } \\
\hline Mean & 2.28134 & 0.51268 & 5.20724 & 2.41112 & 3.82478 & 4.79803 \\
\hline Median & 2.31785 & 0.50651 & 5.26195 & 2.37822 & 3.84646 & 4.67715 \\
\hline Maximum & 2.33457 & 0.62118 & 5.30859 & 2.50637 & 3.87419 & 5.49557 \\
\hline Minimum & 2.14613 & 0.43933 & 5.03779 & 2.33726 & 3.76245 & 3.68851 \\
\hline Std. Dev. & 0.07907 & 0.0667 & 0.11284 & 0.07986 & 0.04889 & 0.74529 \\
\hline Skewness & -1.21284 & 0.817588 & -0.67739 & 0.326971 & -0.35235 & -0.48109 \\
\hline Kurtosis & 2.802095 & 2.650114 & 1.890207 & 1.256566 & 1.383959 & 1.996328 \\
\hline
\end{tabular}

Source: Data collected from www.ntdvprofit, www.csrbox.com and PROWESS database. Computed by SPSS 20.

Note: CSP- Corporate Social Performance, TA-Total Asset, R\&D- Research and Development, AE-Advertising Expenses, MV-Market Value.

Table - 2: Correlation between Corporate Social Performance and Corporate Financial Performance \& Financial Risk of BSE top 10 Companies during the Study Period from 2014 to 2018

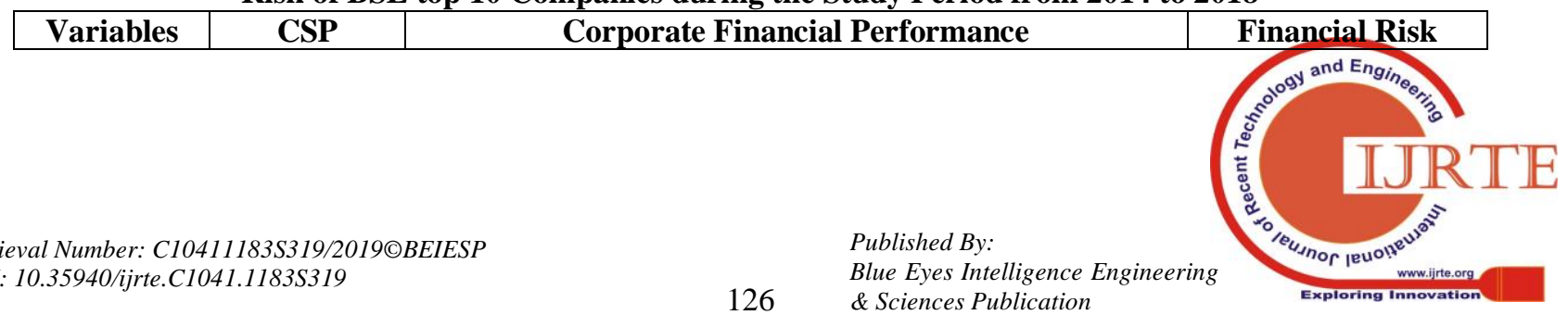




\begin{tabular}{|c|c|c|c|c|c|c|}
\hline & & Sales & T A & R\&D & $\mathbf{A E}$ & M V \\
\hline \multicolumn{7}{|c|}{ Bajaj Finance Ltd } \\
\hline CSP & 1 & 0.979 & 0.998 & 0.984 & 0.829 & -0.176 \\
\hline Sales & 0.979 & 1 & 0.983 & 0.858 & 0.77 & -0.426 \\
\hline T A & 0.998 & 0.983 & 1 & 0.911 & 0.867 & -0.552 \\
\hline R\&D & 0.984 & 0.858 & 0.911 & 1 & 0.958 & -0.691 \\
\hline $\mathbf{A ~ E}$ & 0.829 & 0.77 & 0.867 & 0.958 & 1 & -0.83 \\
\hline M V & -0.176 & -0.426 & -0.552 & -0.691 & -0.83 & 1 \\
\hline \multicolumn{7}{|c|}{ Reliance Industries Ltd } \\
\hline CSP & 1 & 0.963 & 0.991 & 0.982 & 0.263 & 0.92 \\
\hline Sales & 0.963 & 1 & 0.969 & 0.905 & 0.151 & 0.989 \\
\hline T A & 0.991 & 0.969 & 1 & 0.978 & -0.012 & 0.927 \\
\hline $\mathbf{R} \& \mathbf{D}$ & 0.982 & 0.905 & 0.978 & 1 & -0.086 & 0.852 \\
\hline $\mathbf{A ~ E}$ & 0.263 & 0.151 & -0.012 & -0.086 & 1 & 0.242 \\
\hline $\mathbf{M} \mathbf{V}$ & 0.92 & 0.989 & 0.927 & 0.852 & 0.242 & 1 \\
\hline \multicolumn{7}{|c|}{ Bajaj Auto Ltd } \\
\hline CSP & 1 & 0.887 & 0.914 & 0.83 & 0.829 & 0.485 \\
\hline Sales & 0.887 & 1 & 0.624 & 0.487 & 0.448 & 0.125 \\
\hline T A & 0.914 & 0.624 & 1 & 0.721 & 0.726 & 0.034 \\
\hline $\mathbf{R} \& \mathbf{D}$ & 0.83 & 0.487 & 0.721 & 1 & 0.97 & 0.544 \\
\hline $\mathbf{A ~ E}$ & 0.829 & 0.448 & 0.726 & 0.97 & 1 & 0.657 \\
\hline M V & 0.485 & 0.125 & 0.034 & 0.544 & 0.657 & 1 \\
\hline \multicolumn{7}{|c|}{ Tata Motors Ltd } \\
\hline CSP & 1 & -0.915 & 0.462 & -0.425 & -0.432 & -0.152 \\
\hline Sales & -0.915 & 1 & -0.728 & 0.424 & 0.073 & -0.637 \\
\hline TA & 0.462 & -0.728 & 1 & -0.887 & 0.515 & 0.307 \\
\hline R\&D & -0.425 & 0.424 & -0.887 & 1 & -0.613 & 0.162 \\
\hline $\mathbf{A E}$ & -0.432 & 0.073 & 0.515 & -0.613 & 1 & -0.067 \\
\hline M V & -0.152 & -0.637 & 0.307 & 0.162 & -0.067 & 1 \\
\hline \multicolumn{7}{|c|}{ State Bank of India } \\
\hline CSP & 1 & 0.086 & 0.02 & -0.369 & 0.711 & -0.356 \\
\hline Sales & 0.086 & 1 & 0.464 & -0.302 & 0.042 & 0.924 \\
\hline T A & 0.02 & 0.464 & 1 & 0.638 & -0.194 & 0.35 \\
\hline R\&D & -0.369 & -0.302 & 0.638 & 1 & 0.049 & -0.285 \\
\hline $\mathbf{A ~ E}$ & 0.711 & 0.042 & -0.194 & 0.049 & 1 & 0 \\
\hline M V & -0.356 & 0.924 & 0.35 & -0.285 & 0 & 1 \\
\hline
\end{tabular}

\begin{tabular}{|c|c|c|c|c|c|c|}
\hline \multirow{2}{*}{ Variables } & \multirow{2}{*}{ CSP } & \multicolumn{4}{|c|}{ Corporate Financial Performance } & \multirow{2}{*}{$\begin{array}{c}\text { Financial Risk } \\
\text { M V }\end{array}$} \\
\hline & & Sales & T A & R\&D & $\mathbf{A ~ E}$ & \\
\hline \multicolumn{7}{|c|}{ Hindustan Unilever Ltd } \\
\hline CSP & 1 & 0.842 & 0.982 & -0.71 & -0.907 & -0.68 \\
\hline Sales & 0.842 & 1 & 0.933 & -0.402 & -0.639 & 0.616 \\
\hline TA & 0.982 & 0.933 & 1 & -0.548 & -0.675 & 0.691 \\
\hline R\&D & -0.71 & -0.402 & -0.548 & 1 & 0.929 & 0.126 \\
\hline $\mathbf{A E}$ & -0.907 & -0.639 & -0.675 & 0.929 & 1 & 0.058 \\
\hline M V & -0.68 & 0.616 & 0.691 & 0.126 & 0.058 & 1 \\
\hline \multicolumn{7}{|c|}{ NTPC Ltd } \\
\hline CSP & 1 & -0.843 & -0.915 & 0.992 & 0.751 & -0.296 \\
\hline Sales & -0.843 & 1 & 0.91 & 0.814 & -0.523 & 0.702 \\
\hline T A & -0.915 & 0.91 & 1 & 0.83 & -0.764 & 0.692 \\
\hline $\mathrm{R} \& \mathrm{D}$ & -0.992 & 0.814 & 0.83 & 1 & -0.811 & 0.331 \\
\hline $\mathbf{A ~ E}$ & 0.751 & -0.523 & -0.764 & -0.811 & 1 & -0.126 \\
\hline M V & -0.296 & 0.702 & 0.692 & 0.331 & -0.126 & 1 \\
\hline \multicolumn{7}{|c|}{ ITC Ltd } \\
\hline CSP & 1 & -0.141 & 0.992 & -0.625 & 0.331 & 0.998 \\
\hline Sales & -0.141 & 1 & -0.034 & -0.34 & -0.123 & -0.11 \\
\hline TA & 0.992 & -0.034 & 1 & -0.659 & 0.65 & 0.941 \\
\hline R\&D & -0.625 & -0.34 & -0.659 & 1 & -0.738 & -0.639 \\
\hline $\mathbf{A ~ E}$ & 0.331 & -0.123 & 0.65 & -0.738 & 1 & \\
\hline
\end{tabular}


Relationship between Corporate Social Performance, Corporate Financial Performance and Financial Risk in Indian Firms

\begin{tabular}{|c|c|c|c|c|c|c|}
\hline MV & 0.998 & -0.11 & 0.941 & -0.639 & 0.483 & 1 \\
\hline \multicolumn{7}{|c|}{ Asian Paints Ltd } \\
\hline CSP & 1 & 0.938 & 0.995 & 0.954 & 0.19 & 0.682 \\
\hline Sales & 0.938 & 1 & 0.851 & 0.96 & 0.23 & 0.843 \\
\hline $\mathbf{T ~ V}$ & 0.995 & 0.851 & 1 & 0.899 & 0.006 & 0.551 \\
\hline R\&D & 0.954 & 0.96 & 0.899 & 1 & 0.363 & 0.661 \\
\hline $\mathbf{A} \mathbf{E}$ & 0.19 & 0.23 & 0.006 & 0.363 & 1 & -0.037 \\
\hline M V & 0.682 & 0.843 & 0.551 & 0.661 & -0.037 & 1 \\
\hline \multicolumn{7}{|c|}{ Bharathi Airtel Ltd } \\
\hline CSP & 1 & 0.898 & 0.963 & 0.145 & 0.97 & 0.915 \\
\hline Sales & 0.898 & 1 & 0.729 & 0.68 & -0.401 & 0.79 \\
\hline $\mathbf{T A}$ & 0.963 & 0.729 & 1 & 0.179 & 0.203 & 0.915 \\
\hline $\mathbf{R} \& \mathbf{D}$ & 0.145 & 0.68 & 0.179 & 1 & -0.303 & 0.426 \\
\hline $\mathbf{A ~ E}$ & 0.97 & -0.401 & 0.203 & -0.303 & 1 & 0.1 \\
\hline M V & 0.915 & 0.79 & 0.915 & 0.426 & 0.1 & 1 \\
\hline
\end{tabular}

Source: Data collected from www.ntdvprofit, www.csrbox.com and PROWESS database. Computed by SPSS 20.

Note: CSP- Corporate Social Performance, TA-Total Asset, R\&D- Research and Development, AE-Advertising Expenses, MV-Market Value.

\section{REFERENCES}

1. Wood, D.J. (1991). “Corporate Social Performance Revisited”. Academy of Management Journal, 16 (4), 691-718.

2. Arche B. Carroll. (1979). "A Three-Dimensional Conceptual Model of Corporate Performance”. Academy of Management Review, 4(4), 497-505.

3. May-may Meijer and Theo schuyt, (2005). "Corporate Social Performance as a Bottom Line for Consumers”. Business and Society, 44 (4), 442-461.

4. James H. Davis. (1973). "Group Decision and Social Interaction: A Theory of Social Decision Schemes”. Psychological Review, 80(2), 97-125.

5. Frederick, W.C. (1994). "From CSR1 to CSR2: The Maturing of Business and Society Thought". Business and Society, 33 (2), 150-164.

6. Donna J. Wood, (2010), "Measuring Corporate Social Performance: A Review", International Journal of Management Reviews, 50-84.

7. Sandra A. Waddock and Samuel B. Graves. (1997). "The Corporate Social Performance and Financial Performance Link". Strategic Management Journal, 18 (4), 303-319.

8. Orlitzky, M., Schmidt, F. L., Rynes, S. L. (2003). "Corporate social and financial performance: A meta-analysis”. Organization Studies, 24 403-441.

9. Philip L. Cochran and Robert A. Wood, (1984). "Corporate Social Responsibility and Financial Performance". The Academy of Management Journal, 27 (1), 42-56.

10.Conine, T. E. and G. P. Madden, (1987). "Corporate Social Responsibility and Investment Value: The Expectational Relationship". Handbook of Business Strategy 1986/1987 Yearbook, $18-1$ to $18-9$.

11.Reimann, B. C. (1975). "Organizational Effectiveness and Management's Public Values: A Canonical Analysis". Academy of Management Journal, 18, 224-241.

12.Wartick, S. L. (1988). "How Issues Management Contributes to Corporate Performance”. Business Forum, 13, 16-22.

13.Lu, W., Chau, K., Wang, H., \& Pan, W. (2014). "A decade's debate on the nexus between corporate social and corporate financial performance: A critical review of empirical studies 2002-2011". Journal of Cleaner Production, 79, 195-206.

14.John E. Grable. (2000). "Financial Risk Tolerance and Additional Factors That Affect Risk Taking in Everyday Money Matters". Journal of Business and Psychology, 14 (4), 625-630.

15.Winterich, K. P., and Nenkov, G. Y. (2015). "Save Like the Joneses How Service Firms Can Utilize Deliberation and Informational Influence to Enhance Consumer Well-Being”. Journal of Service Research, 18(3), 384-402.

16.Nuttall, J., and Jahnke, W. (2000). "Does asset allocation policy explain 40, 90, or 100 percent of performance? Comments". Financial Analysts Journal, 56(3), 16-19.

17.Brüggen, E. C., Hogreve, J., Holmlund, M., Kabadayi, S., and Löfgren, M., (2017). "Financial well-being: A conceptualization and research agenda”. Journal of Business Research, 79, 228-237.
18.Hill, R. P., Ainscough, T., Shank, T., and Manullang, D. (2007). "Corporate Social Responsibility and Socially Responsible Investing. A Global Perspective". Journal of Business Ethics, 70(2), 165-174.

19.Waddock, S. and Graves, S. (1997). "The Corporate Social Performance and Financial performance Link". Strategic Management Journal, 18, 303-319.

20.Yongtae Kim and Meir Statman. (2012). "Do Corporations Invest Enough in Environmental Responsibility?". Journal of Business Ethics, 105 (1), 115-129.

21.Callan, S. J., and Thomas, J. M. (2009). "Corporate financial performance and corporate social performance: an update and reinvestigation". Corporate Social Responsibility and Environment Management, 16 (2), 61-78.

22.Margolis, J. D., \& Walsh, J. P. (2003). "Misery loves companies: rethinking social initiatives by business". Administrative Science Quarterly, 48 (2), 268-305.

23.Froot, K., D., Scharfstein, and Stein, J. (1993) "Risk management: Coordinating corporate investments and financing policies". Journal of Finance, 5, 1629-1658.

24.Glaum, M. (2000). "Risikomanagement in deutschen Industrie-und Handelsunternehmungen". Working Paper, Giessen University.

25.Andreas Eichhorn, Werner Romisch and Isabel Wegner. (2004) "Polyhedral risk measures in electricity portfolio optimization". Proceedings in Applied Mathematics and Mechanics, 4, 7-10.

26.Bowman, E. H. (1978). "Strategy, annual reports, and alchemy". California Management Review, 20, 64-71.

27.Freedman, M. and Jaggi, B. (1982). "Pollution Disclosures, Pollution Performance and Economic Performance". Omega, 10, 167-176.

28.Fry, F., and Hock, R. (1976). "Who Claims Corporate Responsibility? The Biggest and the Worst". Business and Society Review/Innovation, $18,62-65$.

29. Gerwin Van der Lean, Hans Van Ees and Arjen Van Witteloostujin. (2008). "Corporate Social and Financial Performane: An Extended Stakholder Theory, and Empirical Test with Accounting Measures". Journal of Business Ethics, 79, 299-310. 